\title{
GENETICS OF HYDROXYACID OXIDASE ISOZYMES IN THE MOUSE: LOCALISATION OF Hao-2 ON LINKAGE GROUP XVI
}

\author{
ROGER S. HOLMES \\ MRC Radiobiology Unit, Harwell OX11 ORD, England
}

Received 6.vii.78

\begin{abstract}
SUMMARY
Electrophoretic variants of individual isozymes of $L$ - $\alpha$-hydroxyacid oxidase (HAOX-B4) and amylase (AMY-A) in an Asian subspecies of mouse, Mus musculus castaneus, have been used to localise the gene encoding the HAOX B subunit. The structural gene loci for these isozymes (Hao-2 and $A m y-I)$ are apparently linked ( $4.9 \pm 2.4$ per cent recombinants) in this organism, which places $\mathrm{Hao-2}$ on linkage group XVI, since previous studies by Eicher and coworkers (1976) have localised Amy-1 on this chromosome.
\end{abstract}

\section{INTRODUCTION}

L- $\alpha$-HYDROXYACID OXIDASE (HAOX; E.C. 1.1.3.1) exists as two isozymes in mouse tissues which are tetrameric proteins in dilute solutions (designated A4 and B4) and are encoded by distinct genetic loci (HaO-1 and Hao-2 respectively) (Duley and Holmes, 1974; Phillips et al., 1976; Holmes, 1977). HAOX-A4 preferentially oxidises short-chain aliphatic substrates and is commonly referred to as glycolate oxidase, whereas HAOX-B4 utilises long chain aliphatic and aromatic substrates (Kun et al., 1954; Robinson et al., 1962; Nakano et al., 1968). These isozymes are differentially localised in mouse liver (A4) and kidney (B4) and are predominantly found within peroxisomes or in the extra-particulate cytoplasm of these tissues (see Masters and Holmes, 1977).

Previous genetic analyses of peroxisomal enzymes have demonstrated that Hao-I and $C s$ (the structural gene for mouse catalase) are linked on chromosome 2 of the mouse (Holmes and Duley, 1975). In contrast, however, Hao-2 and Dao (the structural gene for D-amino acid oxidase) are not linked to thse loci in this organism (Holmes, 1976; Holmes, 1977). In this communication, it has been demonstrated that Hao-2 is localised on linkage group XVI near $A m y-1$ (the locus encoding one of the isozymes of mouse amylase).

\section{Materials and methods}

Mice. Male $\mathrm{G} 57 \mathrm{BL} / 10$ inbred mice and female $\mathrm{F}_{1}$ hybrid mice derived from matings between male Mus musculus castaneus and female C57BL/10 inbred mice provided the necessary backcross offspring which were used to examine segregation and the possible linkage relationship between $\mathrm{HaO}_{\mathrm{O}} \mathrm{2}$ and $A m y-1$ loci.

\section{(i) Chemicals}

Phenazine methosulphate (PMS), methyl thiazolylblue (MTT), agarose, DL-p-hydroxyphenyllactate, Triton X-100, Tris (hydroxymethyl aminomethane), starch and glycine were purchased from Sigma Chemicals (St Louis, Missouri). 
(ii) Homogenate preparation

Kidneys were excised from freshly killed mice, rinsed in cold distilled water and homogenised in $50 \mathrm{mM}$ Tris $\mathrm{HGl} p \mathrm{H} 8 \cdot 0,0 \cdot 1$ per cent Triton $\mathrm{X}-100$ buffer (1 kidney $+0.5 \mathrm{ml}$ buffer) using an Ultra-Turrax homogeniser. Animals were $6-8$ weeks in age when examined. The homogenates were then centrifuged $(45,000 \times g, 30 \mathrm{~min}$.) prior to electrophoresis.

\section{(iii) Gel electrophoresis and histochemical staining}

Kidney supernatants were subjected to zone electrophoresis on Titan III cellulose acetate plates $(60 \times 75 \mathrm{~mm})$ (Helena Labs., Texas) with Trisglycine buffer (25 mM Tris; $192 \mathrm{mM}$ glycine) $p \mathrm{H} 8.5$. A voltage of $250 \mathrm{~V}$ was applied for $25 \mathrm{~min}$. The plates were then stained for activity and photographed.

HAOX-B4 was stained by modifying an unpublished agar-overlay technique of Eicher. Two $\mathrm{ml}$. of an agarose solution $(360 \mathrm{mg} / 25 \mathrm{ml})$ at $55^{\circ} \mathrm{C}$ was mixed with an equal volume of a solution containing buffer, substrate and histochemicals, poured over the cellulose acetate plate. Following incubation at $37^{\circ} \mathrm{C}$, the agar overlay was washed from the plate with distilled water and the plate subsequently rinsed in distilled water to remove background stain and dried overnight at $37^{\circ} \mathrm{C}$. The final concentrations in the $4 \mathrm{ml}$ of agar overlay solution were Tris- $\mathrm{HCl}(p \mathrm{H} 8.0), 100 \mathrm{mM}$; DL-p-hydroxyphenyllactate, $6.25 \mathrm{mM}$; PMS, $0.3 \mathrm{mM}$; MTT, $0.9 \mathrm{mM}$. A control stain was also used to reveal oxidase activity in the absence of substrate; Tris HCl ( $p \mathrm{H} 8.0$ ), $100 \mathrm{mM}$; PMS, $0.3 \mathrm{mM}$; MTT, $0.9 \mathrm{mM}$.

Amylase isozymes were stained according to the unpublished procedure of Eicher. An agar-starch gel (2 per cent agarose; 0.5 per cent soluble starch; 0.85 per cent $\mathrm{NaCl}$ ) was prepared in a Petri dish, and the cellulose acetate plate after electrophoresis placed face down on to the gel. Following incubation at $37^{\circ} \mathrm{C}$ for $20 \mathrm{~min}$., the plate-gel interface was exposed and the gel treated with 0.5 per cent iodine solution to reveal zones of amylase isozyme activity.

\section{Results AND Discussion}

Electrophoretic variants of $\alpha$-amylase from the saliva and pancreas of feral and inbred Mus musculus have been reported by Sick and Nielsen (1964) and Kaplan and co-workers (1973). Three loci have been postulated for this enzyme which are apparently differentially expressed in tissues of the mouse. The locus encoding salivary (submaxillary gland) amylase has been designated $A m y$-1, whereas two additional loci have been proposed for the pancreatic isozymes $(A m y-2, A m y-3)$. Only the $A m y-1$ and $A m y-2$ loci exhibited electrophoretic variation between inbred strains, and genetic analyses have demonstrated tight linkage for these genes at the centromeric end of linkage group XVI (Sick and Nielsen, 1964; Eicher et al., 1976). In the present study, both $A m y-1$ and $A m y$-2 gene products were observed in kidney extracts and the genetic variation previously reported for $A m y-1$ in castaneus mice (Kaplan et al., 1973) was used as a gene marker for chromosome 12.

Eighty-two progeny from a backcross of (G57BL/10 울astaneus $\widehat{0}) \mathrm{F}_{1}$ $q \times \mathrm{C} 57 \mathrm{BL} / 10$ of were examined for segregation at the Hao-2 and $A m y-1$ loci 
(table 1). The variants were inherited in a normal Mendelian fashion with two alleles in each case showing co-dominant expression. The loci exhibited a recombination frequency of $4.9 \pm 2 \cdot 4$ per cent and the variation observed from the expected $1: 1: 1: 1$ ratio for unlinked loci was significant $\left(\chi^{2}=\right.$ $67 \cdot 0 ; 3$ d.f.), thus indicating that these loci are co-ordinately localised on linkage group XVI.

A previous study of the genetic control of kidney HAOX (B4 isozyme) has demonstrated linkage of $\mathrm{Hao-2}$ with $\mathrm{Adh}-3$, the locus encoding the $\mathrm{C}_{2}$ isozyme of alcohol dehydrogenase (ADH) in mouse tissue (Holmes, 1977).

TABLE 1

Two-point recombination cross between $\mathrm{Hao}-2$ and Amy-1*

\begin{tabular}{|c|c|c|c|c|c|c|c|c|}
\hline \multirow[b]{2}{*}{$\begin{array}{l}\text { Parents } \\
(q \times \delta)\end{array}$} & \multirow[b]{2}{*}{$\begin{array}{l}H \overline{H a o}-2^{\mathrm{a}} \\
H_{a O}-2^{\mathrm{b}}\end{array}$} & \multicolumn{3}{|c|}{ Parentals } & \multicolumn{4}{|c|}{ Recombinants } \\
\hline & & $\begin{array}{l}A m y-I^{\mathrm{a}} \\
A m y_{*} I^{\mathrm{b}}\end{array}$ & $\begin{array}{l}H a O-2^{\mathrm{a}} \\
H a O-2^{\mathrm{a}}\end{array}$ & $\begin{array}{l}A m y-1 \\
A m y-1^{\mathrm{a}}\end{array}$ & $\begin{array}{l}\operatorname{HaO}_{H a O} 2^{\mathrm{a}} \\
2^{\mathrm{a}}\end{array}$ & $\begin{array}{l}A m y-1 \\
A m y-I^{b}\end{array}$ & $\begin{array}{l}H a O-2^{\mathrm{a}} \\
\mathrm{HaO}-2^{\mathrm{b}}\end{array}$ & $\begin{array}{l}A m y-I^{\mathrm{a}} \\
A m y-I^{\mathrm{a}}\end{array}$ \\
\hline$(\mathrm{C} 57 \mathrm{BL} / 10 \times$ castaneus $) \times \mathrm{C} 57 \mathrm{BL} / 10$ & & 0 & & 38 & & 3 & & 1 \\
\hline Total & & & 78 & & & & 4 & \\
\hline
\end{tabular}

* Recombination frequency $=4 \cdot 9 \pm 2 \cdot 4$ per cent; variation from $1: 1: 1: 1$ ratio for unlinked loci was significant $\left(\chi^{2}=67 \cdot 0\right.$ 3 d.f.; $\mathbf{P} \sim 2 \cdot 1 \times 10^{-14}$ ), indicating that the two loci are linked.

The localisation of these genes on linkage group XVI has been confirmed by other experiments which have demonstrated linkage between $V a$ (varitint-a coat colour gene on linkage group XVI) Cattanach and Moseley, 1973), and Adh-3 in mice (Holmes, unpublished results). Further genetic experiments are under way in this laboratory to establish the gene order of these biochemical loci, Hao-2, Amy-1 and $A d h$-3, with respect to previously mapped genes, $V a$ and de (droopy ear).

It may be concluded from this and a previous study (Duley and Holmes, 1974) that the A4 and B4 isozymes of mouse HAOX are encoded by separate loci (Hao-1 and Hao-2 respectively) localised on separate chromosomes on the mouse genome. Hao-1 has been mapped within 8 centiMorgans of the Cs gene encoding catalase on chromosome 2 (Holmes and Duley, 1975) whereas $H a 0-2$ is localised on linkage group XVI near $A m y-1$.

Acknowledgements.-I am grateful to Dr Mary Lyon and other members of the Genetics Section of the MRC Radiobiology Unit for their continued advice and assistance in supplying mice for this project; to Dr J. Vennart for providing the research facilities; to $\mathrm{Dr} J$. C. Heatherington and Dr V. Chapman for supplying the $F_{1}$ ㅇ (castaneus $\times$ C57BL/10) hybrid mice; and to Dr Eva Eicher for making available details of the cellulose acetate electrophoresis and histochemical staining procedures prior to publication.

\section{REFERENGES}

CATTANACH, B. M., AND moseley, K. 1973. Nondisjunction and reduced fertility caused by tobacco mouse metacentric chromosomes. Cytogenet. Cell. Genet., 12, 264-287.

DULEY, J. A., AND Holmes, R. s. 1974. $\alpha$-Hydroxyacid oxidase genetics in the mouse: evidence for two genetic loci and a tetrameric subunit structure for the liver isozyme. Genetics, 76, 93-97.

eicher, E. M., Womack, J. E., AND southard, J. L. 1976. Mouse Newes Letter, 54, 41 (private communication).

Holmes, R. s. 1976. Genetics of peroxisomal enzymes in the mouse: non-linkage of D-amino acid oxidase locus $(D a o)$ to catalase $(C s)$ and $\mathbf{L}$ - $\alpha$-hydroxyacid oxidase $(H a o-I)$ loci on chromosome 2. Biochem. Genet., 14, 981-987.

Holmes, R. s. 1977. The genetics of $\alpha$-hydroxyacid oxidase and alcohol dehydrogenase in the mouse: evidence for multiple gene loci and linkage between $H a 0-2$ and $A d h-3$. Genetics, 87, 709-716. 
holmes, R. S., AND DUley, J. A. 1975. Biochemical and genetic studies of peroxisomal multiple enzyme systems : $\alpha$-hydroxyacid oxidase and catalase. In Isozymes I, ed. C. L. Markert, pp. 191-211. Academic Press, New York.

KAPLAN, R. S., CHAPMAN, V., AND RUDDLE, F. H. 1973. Electrophoretic variation of $\alpha$-amylase in two inbred strains of Mus musculus. 7. Hered, 64, 155-157.

KUn, E., DECHARY, J. M., AND PITOT, H. C. 1954. The oxidation of glycolic acid by a liver enzyme. F. Biol. Chem., 210, 269-280.

masters, C. J., AND holmes, R. s. 1977. Peroxisomes: new aspects of cell physiology and biochemistry. Physiol. Rev., 57, 816-882.

NAKano, M., Ushijima, y., SAGA, M., TSUTSUmi, Y., AND ASAmI. H. 1968. Aliphatic L- $\alpha-$ hydroxyacid oxidase from rat livers. Purification and properties. Biochem. Biophys. Acta, 167, 9-20.

PHIllips, D. R., DUley, J. A., FENNELl, D. J., AND holmes, R. s. 1976. The self-association of L- $\alpha$-hydroxyacid oxidase. Biochem. Biophys. Acta, 427, 679-687.

ROBINSON, J. C., KEAY, L., MOLINARI, R., AND SIZER, I. w. 1962. L- $\alpha$-hydroxyacid oxidases of hog renal cortex. 7. Biol. Chem., 237, 2001-2010.

SIGK, K., AND NIELSEN, J. T. 1964. Genetics of amylase isozymes in the mouse. Hereditas, 51, 291-296. 